\title{
Pengaruh komponen indeks pembangunan manusia (IPM) terhadap pertumbuhan ekonomi di Kota Jambi Periode 2004-2018
}

\author{
Bayu Permana; *Yulmardi; Junaidi \\ Prodi Ekonomi Pembangunan, Fak. Ekonomi dan Bisnis, Universitas Jambi \\ Email korespondensi :yulmardiedy@yahoo.co.id
}

\begin{abstract}
The purpose of this study is to look at the development of the level of health, the level of education, the level of growth and economic growth in Jambi city and to determine the level of health, the level of education, the level of growth of economic growth in Jambi city. The method that will be used in analyzing data in this study uses descriptive and quantitative analysis methods. The data used in this study are secondary data from the 2004-2018 time series. The tool used to be published uses multiple linear regression. Based on the results of multiple linear regression analysis, it can be concluded that the health level variable has a positive and significant effect on economic growth in Jambi city. The education level variable has no influence on economic growth in Jambi city. expenditure level variables that have a negative influence on economic growth in Jambi city.
\end{abstract}

Keywords: Health index, education index, expenditure index and economic growth

\begin{abstract}
Abstrak
Tujuan penelitian ini adalah untuk melihat perkembangan tingkat kesehatan, tingkat pendidikan, tingkat pengeluaran dan pertumbuhan ekonomi di Kota Jambi dan untuk mengetahui pengarauh tingkat kesehatan, tingkat pendidikan, tingkat pengeluaran terhadap pertumbuhan ekonomi di Kota Jambi. Metode yang akan digunakan dalam menganalisis data dalam penelitian ini adalah menggunakan metode analisis deskriptif dan kuantitatif. Data yang digunakan dalam penelitian ini adalah data sekunder yang bersifat time series 2004-2018. Alat yang digunakan untuk menguji adalah menggunakan regresi linear berganda. Berdasarkan hasil analisi regresi linear berganda dapat disimpulkan bahwa variabel tingkat kesehatan mempunyai pengaruh positif dan signifikan terhadap pertumbuhan ekonomi di Kota Jambi. Variabel tingkat pendidikan tidak mempunyai pengaruh terhadap pertumbuhan ekonomi di Kota Jambi. variabel tingkat pengeluaran mempunyai pengaruh negatif terhadap pertumbuhan ekonomi di Kota Jambi.
\end{abstract}

Kata kunci: Tingkat kesehatan, tingkat pendidikan, tingkat pengeluaran dan pertumbuhan ekonomi. 


\section{PENDAHULUAN}

Pembangunan ekonomi adalah suatu proses kenaikan pendapatan total dan pendapatan perkapita dengan memperhitungkan adanya pertambahan penduduk dan disertai dengan perubahan fundamental dalam struktur ekonomi dan pemerataan pendapatan bagi suatu penduduk suatu daerah. Dengan demikian penduduk merupakan tujuan akhir dan pembangunan sebagai sarana untuk mencapai tujuan. Tujuan pembangunan yakni mewujudkan masyarakat Indonesia yang berkeadilan, berdaya saing, maju, dan sejahtera dalam wadah Negara Kesatuan Republik Indonesia. Pembangunan harus diarahkan sedemikian rupa sehingga setiap tahap semakin mendekati tujuan (Adisasmito, 2013). Hidup layak merupakan hak asasi manusia yang diakui secara universal. Indeks Pembangunan Manusia berperan penting dalam pembangunan perekonomian modern sebab pembangunan manusia yang baik akan menjadikan faktorfaktor produksi mampu dimaksimalkan. Mutu penduduk yang baik akan mampu untuk berinovasi mengembangkan faktor-faktor produksi yang ada. Selain dari pada itu pembangunan manusia yang tinggi mengakibatkan jumlah penduduk akan tinggi pula sehingga akan menaikkan tingkat konsumsi. Hal ini akan mempermudah untuk menggalakkan pertumbuhan ekonomi (Sukirno, 2006).

Jambi adalah sebuah Provinsi di Indonesia yang terletak di pesisir timur di bagian tengah Pulau Sumatra. Jambi adalah satu dari tiga provinsi di Indonesia yang ibu kotanya bernama sama dengan nama provinsinya dan terdiri dari 11 kabupaten/kota. Provinsi Jambi secara geografis terletak antara $0,45^{\circ}$ Lintang Utara, 2,45 Lintang Selatan dan antara $101,10^{\circ}-104,55^{\circ}$ Bujur Timur. Di sebelah Utara berbatasan dengan Provinsi Riau, sebelah Timur dengan Selat Berhala, sebelah Selatan berbatasan dengan Provinsi Sumatra Selatan dan sebelah Barat dengan Provinsi Sumatra Barat dan Provinsi Bengkulu.

Angka Harapan Hidup masyarakat berkaitan erat dengan gizi. Timbulnya kekurangan gizi serta rendahnya derajat kesehatan erat hubungannya dengan kemiskinan sehingga menyebabkan masyarakat tidak dapat memenuhi kebutuhan primer seperti pakaian, rumah dan kesehatan yang memadai. Tingkat pendidikan masyarakat di Kota Jambi dapat dilihat dari Angka Harapan Lama Sekolah, untuk kota Jambi pada tahun 2014 13,6 Tahun, mengalami kenaikan pada tahun 2015 sebesar 13.8 Tahun. Untuk rata-rata lama sekolah bagi penduduk yang berusia 5 Tahun keatas pada tahun 2014 di Kota Jambi adalah 10.6 Tahun dan mengalami kenaikan pada tahun 2016 menjadi 10,7 Tahun. Faktor yang mempengaruhi selain pendapatan adalah pendidikan dan kesejahteraan masyarakat. Sebab ketiga faktor ini mempunyai kedudukan essensial didalam menentukan menentukan kualitas masyarakat, dan ketiga faktor inilah dan mempengaruhi produktivitas masyarakat yang pada akhirnya akan menentukan pula tingkat kesejahteraan mereka (Syamsuddin, 2014).

Indikator harapan hidup dapat menggambarkan derajat kesehatan masyarakat sebagaimana yang telah dinyatakan dalam Sistem Kesehatan Nasional (SKN) bahwa tujuan pembangunan kesehatan adalah tercapainya kemampuan masyarakat yang optimal sebagai salah satu unsur kesejahteraan umum dari tujuan nasional. Angka Harapan Hidup kota Jambi pada tahun 2014 sebesar 72,31 Tahun, lalu pada tahun 2016 terjadi peningkatan menjadi 72.32 Tahun. Selanjutnya tingkat kesejahteraan masyarakat dapat diukur melalui Indikator ekonomi, indikator ekonomi disini berupa Pengeluaran per Kapita yang disesuaikan untuk melihat daya beli masyarakat Kota Jambi, berikut datanya, pada tahun 2014 Pengeluaran Per Kapita Disesuaikan sebesar Rp 10.355.000, dan selanjutnya mengalami kenaikan pada tahun 2015 menjadi Rp 10.890.000. 
Parameter yang dapat dijadikan tolak ukur keberhasilan pembangunan suatu daerah adalah tingkat pertumbuhan ekonomi. Oleh karena itu, setiap daerah akan selalu berupaya untuk mencapai pertumbuhan ekonomi yang optimal untuk membawa daerahnya kepada kehidupan yang lebih baik. Setiap pemerintahan akan mengukur keberhasilan perekonomian daerahnya dengan berbagai indikator yang paling representatif. Tentunya hal ini untuk mengetahui kemampuan kerja elemen pemerintahan dan semua pihak yang berkepentingan (Junaidi, 2009).

Pertumbuhan ekonomi berarti perkembangan kegiatan dalam perekonomian yang menyebabkan barang dan jasa yang diproduksi bertambah dan kemakmuran masyarakat meningkat. Jambi sebagai salah satu kota di Provinsi Jambi selama 5 tahun terakhir terus mengalami fluktuasi pertumbuhan ekonomi. Selama periode 2014-2018 laju pertumbuhan ekonomi tertinggi pada tahun 2014 yakni sebesar $8,5 \%$, namun pada tahun 2014 terjadi penurunan sebesar $0,33 \%$ yakni $8,17 \%$ dan terus menurun pada tahun 2015 sebesar 5,56\% dan mengalami kenaikan pada tahun 2016 sebesar 6,81\% hingga pada tahun 2018 laju pertumbuhan ekonomi menurun drastis sebesar 4,71\%.

Fluktuasi ini disebabkan oleh dominasi sektor pertanian sebagai sumber pertumbuhan ekonomi terbesar, ketika sektor pertanian yang ketergantungannya terhadap iklim dan resiko gagal panen akibat hama/penyakit mengalami guncangan maka nilai pertumbuhan ekonomi akan mengalami penurunan secara signifikan. Hal ini dapat menjadi penghalang bagi pertumbuhan ekonomi yang selama ini dicanangkan oleh pemerintah. Faktor lain yang mempengaruhi adalah tingkat kemiskinan dan populasi penduduk. Jumlah penduduk miskin di Kota Jambi pada tahun 2007 hanya sebesar 5,04 persen dan bukan merupakan jumlah penduduk miskin terbesar di Provinsi Jambi saat itu. Sedangkan Jumlah penduduk yang besar apabila diikuti dengan kualitas yang memadai merupakan modal pembangunan yang handal, namun demikian apabila kualitasnya rendah justru akan menjadi beban pembangunan. Adapun konsekuensi negatif dari pertumbuhan penduduk, yakni berdampak terhadap pertumbuhan ekonomi, kemiskinan, ketimpangan pendapatan, pendidikan, kesehatan, ketersediaan bahan pangan, lingkungan hidup, dan migrasi internasional (Todaro, 2013).

Indeks Pembangunan Manusia dan pertumbuhan ekonomi ini, memiliki hubungan yang erat. IPM yang tinggi akan mendorong tercapainya pertumbuhan ekonomi yang tinggi (Nyoman, 2014). Sejalan uraian diatas maka penelitian ini mencoba menganalisis "Pengaruh komponen Indeks Pembangunan Manusia (IPM) terhadap pertumbuhan ekonomi di kota Jambi periode 2004-2018"

\section{METODE PENELITIAN \\ Jenis data dan sumber data}

Data yang dipergunakan dalam penelitian ini adalah data sekunder yaitu data yang bukan diusahakan sendiri pengumpulannya oleh peneliti, Data sekunder yang digunakan adalah data dari deret berkala (time series) dari tahun 2004 - 2018 di Kota Jambi. Metode pengumpulan data yang dibutuhkan dalam penelitian ini digunakan beberapa teknik dan alat pengumpulan data sebagai berikut:

Penelitian ini studi kepustakaan dilakukan dengan cara membaca dan mempelajari sejumlah buku, literatur, jurnal ilmiah, website internet untuk mendapatkan kerangka teori yang menjadi landasan dalam penelitian ini. Dan data yang digunakan adalah data sekunder yang diperoleh dari BPS (Badan Pusat Statistik), yaitu: Umur harapan hidup, rata-rata lama sekolah, harapan lama sekolah, pengeluaran perkapita dan pertumbuhan ekonomi. 


\section{Metode analisis deskriptif}

Perkembangan tingkat kesehatan, tingkat pendidikan, tingkat pengeluaran dan tingkat pertumbuhan ekonomi di Kota Jambi tahun 2004-2018 maka akan digunakan metode analisis deskriptif dengan rumus :

\section{Tingkat kesehatan}

$y$ Kesehatan $=\frac{\text { Kesehatan }_{t}-\text { Kesehatan }_{t-1}}{\text { Kesehatan }_{t-1}} \times 100 \%$

Dimana: $\quad y$ Kesehatan $\quad=$ Perkembangan tingkat umur harapan hidup

Kesehatan $_{t} \quad=$ Tingkat umur harapan hidup di tahun $\mathrm{t}$

Kesehatan $_{t-1}=$ Tingkat umur harapan hidup tahun sebelumnya

\section{Tingkat pendidikan}

$y$ Pendidikan $=\frac{\text { Pendidikan }_{t} \text { Pendidikan }_{t-1}}{\text { Pendidikan }_{t-1}} \times 100 \%$

Dimana: $y$ Pendidikan $\quad=$ Perkembangan tingkat rata-rata harapan lama sekolah dan rata- rata lama sekolah

Pendidikan $_{t}=$ Tingkat rata-rata harapan lama sekolah dan rata-rata lama sekolahdi tahun $\mathrm{t}$

Pendidikan $_{t-1}=$ Tingkat rata-rata harapan lama sekolah dan rata-rata lama sekolah tahun sebelumnya

\section{Tingkat pengeluaran}

$y$ Pengeluaran $=\frac{\text { Pengeluaran }_{t}-\text { Pengeluaran }_{t-1}}{\text { Pengeluaran }_{t-1}} \times 100 \%$

Dimana : yPengeluaran = Perkembangan tingkat pengeluaran perkapita

Pengeluaran $_{t} \quad=$ Tingkat pengeluaran perkapita di tahun $\mathrm{t}$

Pengeluaran $_{t-1} \quad=$ Tingkat pengeluaran perkapita tahun sebelumnya

\section{Metode analisis kuantitatif}

Metode untuk menjawab pertanyaan kedua rumusan masalah yaitu bagaimana pengaruh tingkat kesehatan, tingkat pendidikan dan tingkat pengeluaran terhadap pertumbuhan ekonomi di kota Jambi tahun 2004-2018 maka akan digunakan metode analisis kuantitatif dengan menggunakan alat analisis regresi linear berganda (Sugiyono, 2015). Model yang digunakan dalam penelitian ini dijabarkan dalam fungsi sebagai berikut :

$P E=b_{0}+b_{1}$ Tkesehatan $+b_{2}$ Tpendidikan $+b_{3}$ Tpengeluaran $+e$

Keterangan: $P E \quad=$ Pertumbuhan ekonomi

$b_{0} \quad=$ Konstanta persamaan regresi

$b_{1}, b_{2}, b_{3} \quad=$ Koefisien regresi masing masing variabel

Tkesehatan $=$ Umur harapan hidup

Tpendidikan = Rata harapan lama sekolah dan rata lama sekolah

TPengeluaran = Pengeluaran perkapita

$e \quad=$ Standar error 


\section{Pengujian kriteria statistik}

\section{Uji statistik F (Uji simultan)}

Uji $\mathrm{F}$ atau uji simultan pada dasarnya digunakan untuk mengetahui apakah variabel independen yang dimaksudkan dalam model mempunyai pengaruh secara bersama atau simultan terhadap variable dependen (Widiyanto, 2013). Dengan tingkat signifikan sebesar 0,05 .

\section{Uji statistik t (Uji parsial)}

Uji t atau uji parsial untuk menjawab rumusan masalah nomor dua. Uji t pada dasarnya menunjukan seberapa jauh pengaruh satu variable independen secara individual dalam menerangkan variable dependen (Ghozali, 2009).

\section{Koefisien determinasi $\left(\mathbf{R}^{\mathbf{2}}\right)$}

Nilai $R^{2}$ yang kecil berarti kemampuan variabel-variabel independen dalam menjelaskan variasi variabel dependen amat terbatas. Nilai dari $\mathrm{R}^{2}$ berkisar dari $0-1$ atau $0 \%-100 \%$. Semakin mendekati nilai 1 atau 100\% maka semakin besar pengaruh variable independen terhadap variable dependen (Widiyanto, 2013).

\section{HASIL DAN PEMBAHASAN}

\section{Perkembangan tingkat kesehatan}

Tingkat kesehatan dalam komponen Indeks Pembangunan Manusia adalah Umur harapan hidup (UHH) adalah perkiraan rata-rata tambahan umur seseorang yang diharapkan dapat terus hidup. UHH juga dapat didefinisikan sebagai rata-rata jumlah tahun yang dijalani oleh seseorang setelah orang tersebut mencapai ulang tahun yang ke-x. Pada umumnya ketika membicarakan UHH, yang dimaksud adalah rata-rata jumlah tahun yang akan dijalani oleh seseorang sejak orang tersebut lahir.

Tabel 1. Perkembangan tingkat kesehatan Tahun 2004-2018

\begin{tabular}{ccc}
\hline Tahun & UHH (Tahun) & Perkembangan UHH $(\boldsymbol{\%})$ \\
\hline 2004 & 67,8 & - \\
2005 & 69,4 & 2,36 \\
2006 & 69,7 & 0,43 \\
2007 & 69,8 & 0,14 \\
2008 & 69,8 & 0,00 \\
2009 & 69,8 & 0,00 \\
2010 & 69,9 & 0,14 \\
2011 & 69,9 & 0,00 \\
2012 & 72,3 & 3,43 \\
2013 & 72,3 & 0,00 \\
2014 & 72,3 & 0,00 \\
2015 & 72,3 & 0,00 \\
2016 & 72,3 & 0,00 \\
2017 & 72,3 & 0,00 \\
2018 & 72,4 & 0,14 \\
\hline Rata-rata & $\mathbf{7 0 , 8}$ & $\mathbf{0 , 4 4}$ \\
\hline
\end{tabular}

Sumber : Data diolah, 2019 
Umur harapan hidup (UHH) Kota Jambi Tahun 2004-2018 menunjukkan bahwa melalui keadaan sehat dan berumur panjang dengan tingkat perkembangannya $0,44 \%$, pada tahun 2018 adalah 0,14\% mengalami peningkatan dari tahun sebelumnya. Sedangkan umur harapan hidup yang tertinggi terjadi pada tahun 2012 yaitu sebesar 3,43\% . Menurut data yang telah dipublikasikan oleh Badan Pusat Statistik Kota Jambi peningkatan harapan hidup ini terjadi karena angka kunjungan masyarakat sebagai pengguna layanan kesehatan gratis meningkat. Upaya pemerintah daerah dalam menyediakan fasilitas kesehatan terutama puskesmas pembantu terus mengalami peningkatan. Peningkatan angka harapan hidup menggambarkan membaiknya nutrisi dan kesadaran masyarakat terhadap kesehatan dan lingkungan sehingga akan berpengaruh terhadap membaiknya produktivitas penduduk yang akan berdampak positif pada laju pertumbuhan ekonomi. Semakin tinggi angka harapan hidup seseorang yang berarti semakin lama usia hidup akan meningkatkan produktifitas masyarakat.

\section{Perkembangan tingkat pendidikan}

Indikator dalam pembangunan manusia salah satunya adalah Harapan lama sekolah yang dapat dijadikan ukuran kemajuan suatu bangsa. Harapan Lama Sekolah (RLS) adalah perbandingan antara jumlah penduduk usia 15 tahun ke atas yang dapat membaca dan menulis dengan jumlah penduduk usia 15 tahun ke atas. Batas maksimum untuk angka melek huruf, adalah 100 sedangkan batas minimum 0 (standar UNDP). Hal ini menggambarkan kondisi 100 persen atau semua masyarakat mampu membaca dan menulis, dan nilai nol mencerminkan kondisi sebaliknya. Indikator berikutnya yang masuk ke tingkat pendidikan adalah Rata-rata lama sekolah, Rata-rata Lama Sekolah mengindikasikan semakin tingginya pendidikan yang dicapai oleh masyarakat di suatu daerah. Semakin tinggi rata-rata lama sekolah berarti semakin tinggi jenjang pendidikan yang dijalani. Rata-rata lama sekolah adalah rata-rata jumlah tahun yang dihabiskan oleh penduduk yang berusia 15 tahun ke atas untuk menempuh semua jenis pendidikan formal yang pernah dijalani.

Tabel 2. Perkembangan tingkat kesehatan Tahun 2004-2018

\begin{tabular}{ccccc}
\hline Tahun & $\begin{array}{c}\text { HLS (Harapan } \\
\text { Lama Sekolah) }\end{array}$ & $\begin{array}{c}\text { RLS (Rata- } \\
\text { rata Lama } \\
\text { Sekolah) }\end{array}$ & $\begin{array}{c}\text { Tingkat } \\
\text { Pendidikan } \\
\text { (Tahun) }\end{array}$ & $\begin{array}{c}\text { Perkembangan } \\
\text { Tingkat } \\
\text { Pendidikan(\%) }\end{array}$ \\
\hline 2004 & 12,4 & 6,9 & 9,7 & - \\
2005 & 12,5 & 10,1 & 11,3 & 16,50 \\
2006 & 12,5 & 10,1 & 11,3 & 0,00 \\
2007 & 12,6 & 10,1 & 11,3 & 0,00 \\
2008 & 12,8 & 10,1 & 11,4 & 0,88 \\
2009 & 12,8 & 10,1 & 11,5 & 0,88 \\
2010 & 12,8 & 10,1 & 11,5 & 0,00 \\
2011 & 13,2 & 10,4 & 11,8 & 2,61 \\
2012 & 13,2 & 10,3 & 11,7 & $-0,85$ \\
2013 & 13,2 & 10,6 & 11,9 & 1,71 \\
2014 & 13,6 & 10,6 & 12,1 & 1,68 \\
2015 & 13,8 & 10,6 & 12,2 & 0,83 \\
2016 & 13,8 & 10,7 & 12,2 & 0,00 \\
2017 & 14,2 & 10,7 & 12,4 & 1,64 \\
2018 & 14,6 & 10,7 & 12,6 & 1,61 \\
\hline Rata-rata & $\mathbf{1 3 , 2}$ & $\mathbf{1 0 , 1}$ & $\mathbf{1 1 , 7}$ & $\mathbf{1 , 8 3}$ \\
\hline
\end{tabular}

Sumber : Data diolah, 2019 
Perkembangan tingkat pendidikan tahun 2004-2018 di Kota Jambi bergerak tidak stabil terkadang naik dan terkadang turun. Jika dilihat rata-rata perkembangannya sebesar $1,83 \%$ tahun untuk setiap tahunnya. Dan tabel diatas menunjukkan angka harapan lama sekolah Kota Jambi tertingi pada tahun 2018 untuk penduduk 15 tahun keatas sebesar 12,6 tahun dengan tingkat perkembangan 1,61\%. Sedangkan angka harapan lama sekolah Kota Jambi terendah pada tahun 2004 untuk penduduk 15 tahun keatas sebesar 9,7 tahun dengan tingkat perkembangan 16,50\%. Perkembangan tingkat kesehatan cendrung meningkat setiap tahun.

\section{Perkembangan tingkat pengeluaran}

Tingkat pengeluaran atau pengeluaran perkapita disesuaikan digunakan untuk mengukur standar hidup manusia. Pengeluaran perkapita disesuaikan adalah pengeluaran perkapita dengan harga konsumen dan penurunan utilitas marginal. Pengeluaran perkapita disesuaikan memberikan gambaran tingkat daya beli (Purchasing Power Parity) masyarakat, dan sebagai salah satu komponen yang digunakan dalam melihat status pembangunan manusia di suatu wilayah (Muqorrobin, 2017).

Tabel 3. Perkembangan tingkat pengeluaran

\begin{tabular}{ccc}
\hline Tahun & $\begin{array}{c}\text { Pengeluaran Perkapita } \\
\text { (Ribu Rupiah) }\end{array}$ & $\begin{array}{c}\text { Perkembangan Tingkat } \\
\text { Pengeluaran (Persen) }\end{array}$ \\
\hline 2004 & 9.178 & - \\
2005 & 9.267 & 0,96 \\
2006 & 9.376 & 1,17 \\
2007 & 9.437 & 0,65 \\
2008 & 9.543 & 1,12 \\
2009 & 9.645 & 1,06 \\
2010 & 9.718 & 0,75 \\
2011 & 9.805 & 0,89 \\
2012 & 10.073 & 2,73 \\
2013 & 10.192 & 1,18 \\
2014 & 10.355 & 1,59 \\
2015 & 10.890 & 5,16 \\
2016 & 11.436 & 5,01 \\
2017 & 11.648 & 1,85 \\
2018 & 11.912 & 2,26 \\
\hline Rata-rata & $\mathbf{1 0 . 1 6 5}$ & $\mathbf{1 , 7 6}$ \\
\hline
\end{tabular}

Sumber : Data diolah, 2019

Perkembangan Tingkat Pengeluaran tahun 2004-2018 di Kota Jambi mengalami kenaikan dari tahun ke tahun. Jika dilihat dari rata-rata perkembangannya sebesar 1,76 $\%$ per tahunnya. Tingkat pengeluaran per kapita mengalami peningkatan setiap tahun, dimana yang tertinggi terjadi pada tahun 2015 yaitu sebesar 5,16\% sedangkan untuk terendah pada tahun 2010 yaitu sebesar $0,74 \%$. 


\section{Perkembangan pertumbuhan ekonomi}

Menurut Sukirno (2011), laju pertumbuhan ekonomi adalah kenaikan PDRB tanpa memandang apakah kenaikan itu lebih besar atau lebih kecil.Produk domestik regional bruto adalah jumlah nilai tambah bruto (gross value added) yang timbul dari seluruh sektor perekonomian di suatu wilayah. Pertumbuhan ekonomi menunjukkan pertumbuhan produksi barang dan jasa di suatu wilayah perekonomian dalam selang waktu tertentu. Semakin tinggi tingkat pertumbuhan ekonomi maka semakin cepat proses pertambahan output wilayah sehingga prospek perkembangan wilayah semakin baik. Dengan di ketahuinya sumber-sumber pertumbuhan ekonomi maka dapat ditentukan dari sektor prioritas pembangunan pada daerah yang bersangkutan, dan dapat ditemukan sektor mana yang menddominasi.

Tabel 4. Perkembangan pertumbuhan ekonomi

\begin{tabular}{crc}
\hline Tahun & $\begin{array}{c}\text { PDRB } \\
\text { (Juta Rupiah) }\end{array}$ & Pertumbuhan Ekonomi (Persen) \\
\hline 2004 & $806.660,74$ & 5,16 \\
2005 & $2.506 .910,32$ & 5,69 \\
2006 & $2.655 .444,97$ & 5,93 \\
2007 & $2.845 .549,62$ & 7,16 \\
2008 & $3.020 .126,51$ & 6,14 \\
2009 & 3.215 .391 & 6,47 \\
2010 & $9.657 .924,05$ & 6,66 \\
2011 & $11.932 .755,54$ & 6,97 \\
2012 & $12.848 .141,30$ & 7,67 \\
2013 & $12.848 .141,30$ & 8,50 \\
2014 & $15.080 .229,53$ & 8,17 \\
2015 & $15.921 .206,06$ & 5,56 \\
2016 & $15.921 .206,06$ & 6,81 \\
2017 & $17.728 .338,77$ & 4,68 \\
2018 & $18.699 .511,01$ & 4,71 \\
\hline Rata-rata & $\mathbf{1 2 . 7 9 4 . 8 1 4 , 8 5}$ & $\mathbf{6 , 4 2}$ \\
\hline
\end{tabular}

Sumber : Data diolah, 2019

Laju pertumbuhan ekonomi pada tahun 2004-2018 di Kota Jambi bergerak tidak stabil terkadang naik dan turun dengan tingkat rata-rata perkembangan $6,42 \%$. Kenaikan terendah terjadi pada tahun 2017 sebesar 4,68\% ini berarti terjadi pelambatan pertumbuhan ekonomi atau lesu nya perekonomian pada tahun tersebut, sedangkan pertumbuhan ekonomi tertinggi pada tahun 2013 sebesar 8,50\%.

\section{Uji asumsi klasik}

\section{Uji multikolonieritas}

Uji Multikolonieritas Uji ini bertujuan untuk menguji apakah dalam model regresi ditemukan adanya korelasi antara variabel independen. Berdasarkan aturan Variance Infaltion Factor (VIF) dan tolerance, maka apabila VIF melebihi angka 10 atau tolerance kurang dari 0,10 maka dinyatakan terjadi gejala multikolinieritas. Sebaliknya 61 apabila nilai VIF kurang dari 10 atau tolerance lebih dari 0,10 maka dinyatakan tidak terjadi multikolinieritas. Hasil uji multikolinieritas terdapat pada tabel berikut: 
Tabel 5. Uji multikolonieritas komponen Indeks Pertumbuhan Manusia (IPM) di Kota Jambi Tahun 2004-2018

\begin{tabular}{lcc}
\hline \multicolumn{1}{c}{ Model } & Tolerance & VIF \\
\hline Tingkat Kesehatan &, 192 & 5,202 \\
Tingkat Pendidikan &, 215 & 4,653 \\
Tingkat Pengeluaran &, 290 & 3,454 \\
\hline
\end{tabular}

Sumber : Data diolah, 2019

Berdasarkan tabel diatas menunjukkan bahwa nilai VIF masing-masing variabel kesehatan pendidikan dan pengeluaran dengan nilai VIF $<10$ dan nilai tolerancenya $>$ 0,10 sehingga model regresi dinyatakan tidak terjadi gejala multikolinieritas data.

\section{Uji normalitas}

Pengujian normalitas data digunakan untuk melihat apakah dalam sebuah model regresi, variabel bebas, dan variabel terikat atau keduanya memiliki distribusi normal ataukah tidak. Hasil uji normalitas dapat dilihat sebagaimana gambar berikut:

Normal P-P Plot of Regression Standardized Residual

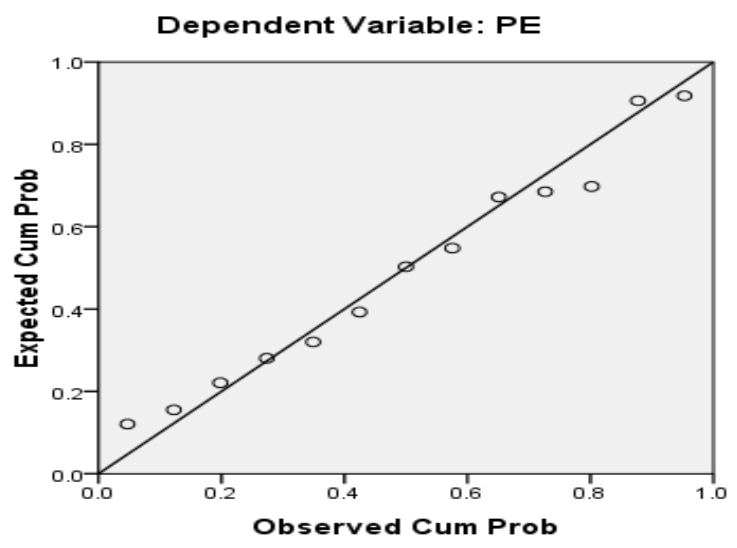

Sumber: Data diolah, 2019

Gambar 1. Grafik histogram IPM Kota Jambi Tahun 2004-2018

Gambar 1 memggambarkan normal probability plot menunjukkan bahwa data menyebar disekitar garis diagonal dan manunjukkan pola distribusi normal, sehingga dapat disimpulkan bahwa asumsi normalitas telah terpenuhi dan layak dipakai untuk memprediksi indeks pembangunan manusia berdasarkan variabel bebasnya.

\section{Uji heteroskedastisitas}

Tujuan dari pengujian ini adalah untuk menguji apakah dalam model regresi terjadi ketidaksamaan varians residual dari satu pengamatan ke pengamatan yang lain. Model regresi yang baik adalah tidak terjadi heteroskedastisitas, dan adapun hasil pengujian ditunjukkan sebagaimana gambar berikut ini: 


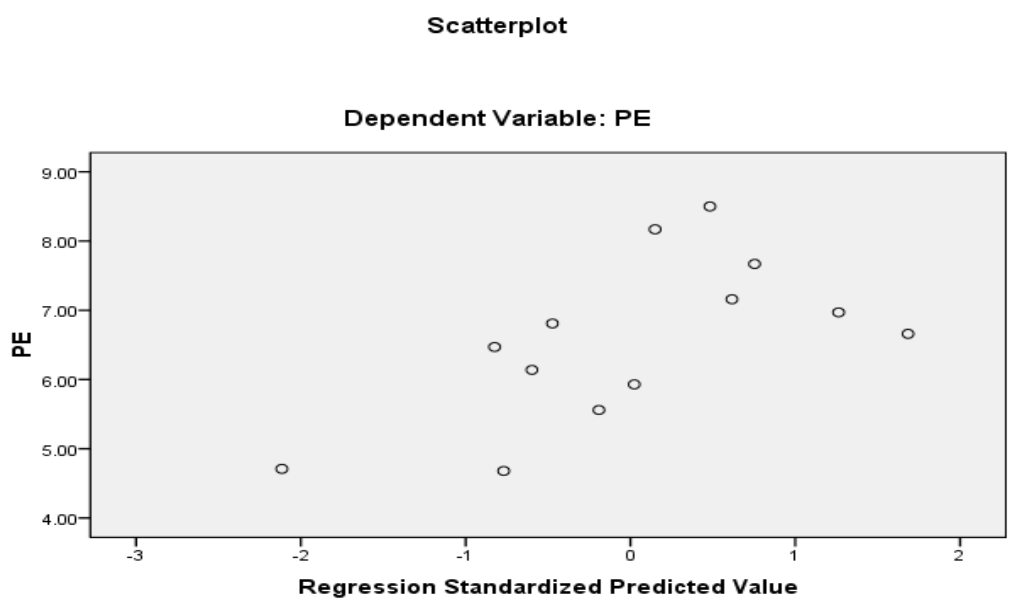

Sumber: Data diolah, 2019

Gambar 1. Grafik histogram IPM Kota Jambi Tahun 2004-2018

Gambar grafik Scatterplot tersebut, terlihat titik-titik menyebar secara acak dan tidak membentuk suatu pola tertentu yang jelas, serta tersebar baik diatas maupun dibawah angka 0 pada sumbu Y. Hal ini berarti tidak terjadi heteroskedastisitas pada model regresi sehingga model regresi layak dipakai untuk memprediksi pengaruh variabel berdasarkan masukan variabel independennya.

\section{Uji hipotesis}

Uji statistik F (Uji simultan)

Uji $\mathrm{F}$ digunakan untuk mengetahui apakah variabel tingkat kesehatan, tingkat pendidikan dan tingkat daya beli secara simultan mempunyai pengaruh yang signifikan terhadap pertumbuhan ekonomi. Hasil analisis dapat dilihat pada tabel berikut:

Tabel 6. Hasil uji statistik F

\begin{tabular}{lrrrrr}
\hline \multicolumn{1}{c}{ Model } & Sum of Squares & \multicolumn{1}{c}{ Df } & Mean Square & \multicolumn{1}{c}{ F } & \multicolumn{1}{c}{ Sig. } \\
\hline Regression & 12,749 & 3 & 4,250 & 7,310 &, $006^{\mathrm{b}}$ \\
Residual & 6,395 & 11 &, 581 & & \\
Total & 19,144 & 14 & & & \\
\hline
\end{tabular}

Sumber : Data diolah, 2019

Hasil uji statistik $\mathrm{F}$ menunjukkan pengaruh variabel (X1) tingkat kesehatan, (X2) tingkat pendidikan, (X3) tingkat pengeluaran, terhadap pertumbuhan ekonomi (Y), diperoleh nilai signifikan 0,006 $<0,05(5 \%)$. Dengan demikian nilai $\mathrm{F}_{\text {hitung }}$ lebih besar dari $\mathrm{F}_{\text {Tabel }}(7,310>3,59)$. Artinya $\mathrm{H}_{1}$ diterima dan $\mathrm{H}_{0}$ ditolak.

\section{Uji statistik t (Uji parsial)}

Uji t merupakan uji yang dilakukan untuk mengetahui pengaruh variabel (X1) tingkat kesehatan, (X2) tingkat pendidikan, (X3) tingkat pengeluaran per Kapita, terhadap pertumbuhan ekonomi (Y). 
Tabel 7. Hasil uji t

\begin{tabular}{lrrrrl}
\hline \multicolumn{1}{c}{ Model } & \multicolumn{1}{c}{ B } & Std. Error & Beta & \multicolumn{1}{c}{ t } & Sig \\
\hline (Constant) & $-48,941$ & 15,280 & & $-3,203$ &, 008 \\
X1 & 1,041 &, 302 & 1,371 & 3449 &, 005 \\
X2 &, 007 &, 638 &, 004 &, 010 &, 992 \\
X3 &,- 002 &, 000 & $-1,396$ & -4309 &, 001 \\
\hline
\end{tabular}

Sumber : Data diolah, 2019

Berdasarkan uji $\mathrm{t}$ variabel tingkat kesehatan sebesar $0,005<0,05$ artinya variabel tingkat kesehatan memiliki pengaruh yang signifikan, variabel tingkat pendidikan sebesar 0,992 > 0,05 artinya variabel tingkat pendidikan tidak memiliki pengaruh yang signifikan, dan variabel tingkat pengeluaran sebesar $0,001<0,05$ artinya variabel tingkat pengeluaran memiliki pengaruh yang signifikasi.

\section{Koefisien determinasi $\left(\mathbf{R}^{2}\right)$}

Nilai koefisien determinasi untuk 3 variabel bebas dan 1 variabel terikat ditentukan dengan nilai adjusted R square. Hasil koefisien determinasi sebagai berikut:

Tabel 8. Hasil uji koefisien determinasi $\mathrm{R}^{2}$

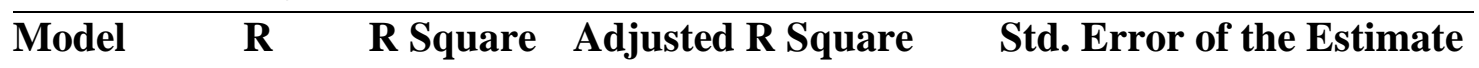

\begin{tabular}{rrrr}
\hline, $816^{\mathrm{a}}$ &, 666 &, 575 &, 762 \\
\hline
\end{tabular}

Sumber : Data diolah, 2019

Besarnya daya ramal model yang diberikan oleh nilai koefisien determinasi yang disimbolkan dengan $\mathrm{R}^{2}$ (R-Square) sebesar 0,666 yang berarti mempunyai daya ramal sebesar $66,6 \%$ atau sekitar $66,6 \%$ variasi naik turunnya pertumbuhan ekonomi dapat dijelaskan oleh model atau dengan kata lain varians perubahan pertumbuhan ekonomi dipengaruhi oleh variabel-variabel (X1) tingkat kesehatan, (X2) tingkat pendidikan, (X3) tingkat pengeluaran, sedangkan sisanya sebesar 33,4\% diakibatkan oleh faktor lain yang tidak dimasukkan dalam model analisis.

\section{Analisis regresi linier berganda}

Analisis regresi dilakukan untuk mengetahui tingkat pengaruh variabel dan menguji hipotesis penelitian yang telah ditetapkan sebelumnya. Hasilnya analisisnya adalah:

Tabel 9. Hasil uji regresi berganda

\begin{tabular}{|c|c|c|c|c|c|}
\hline \multirow[t]{2}{*}{ Model } & \multicolumn{2}{|c|}{$\begin{array}{l}\text { Unstandardized } \\
\text { Coefficients }\end{array}$} & \multirow{2}{*}{$\begin{array}{c}\text { Standardized } \\
\text { Coefficients } \\
\text { Beta } \\
\end{array}$} & \multirow[t]{2}{*}{$\mathbf{T}$} & \multirow[t]{2}{*}{ Sig. } \\
\hline & B & Std. Error & & & \\
\hline (Constant) & $-48,941$ & 15,280 & & $-3,203$ & ,008 \\
\hline $\mathrm{X} 1$ & 1,041 & ,302 & 1,371 & 3449 & ,005 \\
\hline $\mathrm{X} 2$ & ,007 & ,638 & ,004 & ,010 & ,992 \\
\hline $\mathrm{X} 3$ &,- 002 &, 000 & $-1,396$ & -4309 & ,001 \\
\hline
\end{tabular}

Sumber : Data diolah, 2019

Berdasarkan pada hasil koefisien regresi diatas, maka diperoleh persamaan regresi sebagai berikut: $\mathrm{Y}=-48,941+1,041\left(\mathrm{X}_{1}\right)+0,007\left(\mathrm{X}_{2}\right)+-0,002\left(\mathrm{X}_{3}\right)$ 
Berdasarkan persamaan regresi berganda seperti diatas, selanjutnya dapat diinterprestasikan sebagai berikut. Nilai koefisien Y sebesar $-48,941$ berarti apabila variabel tingkat kesehatan $\left(\mathrm{X}_{1}\right)$, tingkat pendidikan $\left(\mathrm{X}_{2}\right)$, dan tingkat pengeluaran $\left(\mathrm{X}_{3}\right)$ sama dengan nol maka pertumbuhan ekonomi (Y) sebesar -48,941. Nilai signifikan $\mathrm{X}_{1}$ tingkat kesehatan sebesar 0,005. Artinya dinyatakan lebih kecil dari taraf $\alpha=5 \%(0,005$ $<0,05)$. Hal ini di tunjukkan dengan nilai $t_{\text {hitung }}$ lebih besar dari $t_{\text {tabel }}(3,449>1,795)$ : 3,449 dari hasil tersebut dapat disimpulkan bahwa variabel tingkat kesehatan $\mathrm{X}_{1}$ mempunyai pengaruh positif dan signifikan terhadap pertumbuhan ekonomi di Kota Jambi. Dengan demikian $\mathrm{H}_{0}$ ditolak dan $\mathrm{H}_{\mathrm{a}}$ di terima. Nilai signifikan $\mathrm{X}_{2}$ tingkat pendidikan sebesar 0,992. Artinya dinyatakan lebih besar dari taraf $\alpha=5 \%(0,992>$ $0,05)$. Hal ini di tunjukkan dengan nilai $t_{\text {hitung }}$ lebih kecil dari $t_{\text {tabel }}(0,010<1,795)$ dari hasil tersebut dapat disimpulkan bahwa variabel tingkat pendidikan $\mathrm{X}_{2}$ tidak mempunyai pengaruh terhadap pertumbuhan ekonomi di Kota Jambi. Dengan demikian $\mathrm{H}_{0}$ diterima dan $\mathrm{H}_{\mathrm{a}}$ di tolak. Nilai signifikan $\mathrm{X}_{3}$ tingkat pengeluaran sebesar 0,001. Artinya dinyatakan lebih kecil dari taraf $\alpha=5 \%(0,001<0,05)$. Hal ini di tunjukkan dengan nilai $t_{\text {hitung }}$ lebih besar dari $t_{\text {tabel }}(-4,309>1,795)$ dari hasil tersebut dapat disimpulkan bahwa variabel tingkat pengeluaran $X_{3}$ mempunyai pengaruh negatif dan signifikan terhadap pertumbuhan ekonomi di Kota Jambi. Dengan demikian $\mathrm{H}_{0}$ ditolak dan $\mathrm{H}_{\mathrm{a}}$ di terima.

\section{KESIMPULAN DAN SARAN \\ Kesimpulan}

Perkembangan tingkat kesehatan di Kota Jambi tahun 2004-2018 naik setiap tahun, tingkat pendidikan mengalami kenaikan setiap tahun, perkembangan tingkat pengeluaran menurun setiap tahun dan pertumbuhan ekonomi naik pertahun. Nilai signifikan tingkat kesehatan dinyatakan lebih kecil dari taraf $\alpha$. Hasil tersebut dapat disimpulkan bahwa variabel tingkat kesehatan mempunyai pengaruh positif dan signifikan terhadap pertumbuhan ekonomi di Kota Jambi. Dengan demikian $\mathrm{H}_{0}$ ditolak dan $\mathrm{H}_{\mathrm{a}}$ di terima. Nilai signifikan tingkat pendidikan dinyatakan lebih besar dari taraf $\alpha$. Hal ini di tunjukkan dengan variabel tingkat pendidikan tidak mempunyai pengaruh terhadap pertumbuhan ekonomi di Kota Jambi. Dengan demikian $\mathrm{H}_{0}$ diterima dan $\mathrm{H}_{\mathrm{a}}$ di tolak. Nilai signifikan tingkat pengeluaran dinyatakan lebih kecil dari taraf $\alpha$. Hal ini dapat disimpulkan bahwa variabel tingkat pengeluaran mempunyai pengaruh negatif dan signifikan terhadap pertumbuhan ekonomi di Kota Jambi. Dengan demikian $\mathrm{H}_{0}$ ditolak dan $\mathrm{H}_{\mathrm{a}}$ di terima.

\section{Saran}

Pembangunan dibidang kesehatan, dan pendidikan harus dilakukan dengan sungguhsungguh karena dapat menaikkan pertumbuhan ekonomi di Kota Jambi dan di bidang pengeluaran per kapita dapat menurunkan pertumbuhan ekonomi. Pembangunan bisa dilakukan dengan cara memperbaiki infrastruktur dan meningkatkan pelayanan di masing-masing bidang kesehatan, pendidikan dan menstabilkan pengeluaran per kapita. Kesejahteraan indeks kesehatan dengan tingkat pendidikan harus diperhatikan lebih serius oleh pemerintah demi meningkatkan pertumbuhan ekonomi yang lebih baik, serta pengeluaran perkapita perlu di stabilkan kembali tiap tahunnya. Bagi penelitian selanjutnya dengan topik sejenis disarankan untuk melakukan kajian yang lebih lanjut dengan memasukkan variabel independen lainnya serta memperpanjang periode penelitian, dan menggunakan alat analisis yag lebih akurat untuk mendapatkan hasil penelitian yang lebih baik. 


\section{DAFTAR PUSTAKA}

Adisasmita, Rahardjo. (2013). Teori-Teori Pembangunan Ekonomi. Graha Ilmu: Yogyakarta.

Ghozali, Imam. (2009). Aplikasi Analisis Multivariate dengan Program SPSS. Edisi Empat. Badan Penerbit Universitas Diponegoro: Semarang.

Junaidi dan Hardiani. (2009). Dasar-dasar Teori Ekonomi Kependudukan. Hamada Prima: Bandung.

Muqorrobin, Moh. (2017). Pengaruh Indeks Pembangunan Manusia terhadap Pertumbuhan Ekonomi Provinsi Jawa Timur. Jurnal Pendidikan Ekonomi. 5 (3), 56-66.

Nyoman, Lilya. (2014). Pengaruh Komponen Indeks Pembangunan Manusia Terhadap Pertumbuhan Ekonomi Provinsi Bali. Jurnal Ekonomi dan Bisnis Universitas Udayana. 3 (3), 106-114.

Sukirno, Sadono. (2011). Makro Ekonomi Teori Pengantar. Edisi Tiga. Raja Grafindo Persada: Jakarta.

Sugiyono. (2015). Metode Penelitian Kuantitatif, Kualitatif, dan R\&D. Alfabeta: Bandung.

Syamsuddin. (2014). Analisis Indeks Pembangunan Manusia Kabupaten Tanjung Jabung Barat. Jurnal Paradigma Ekonomika. 9 (2), 9-16.

Todaro, Michael, P. dan Stephen C. Smith. (2013). Pembangunan Ekonomi di Dunia Ketiga. Edisi Kedelapan. Erlangga: Jakarta.

Widiyanto, M.A. (2013). Statistika Terapan, Konsep dan Aplikasi SPSS/Lisrel dalam Penelitian Pendidikan, Psikologi dan Ilmu Sosial Lainya. Elex Media Komputindo: Jakarta. 